\title{
STRATEGI PENINGKATAN KINERJA KELOMPOK USAHA BERSAMA NELAYAN KOTA CIREBON
}

\author{
Lilik Supriyadi $^{*}$, Mukti Ali², Moch Farid Wadji²
}

${ }^{1}$ Politeknik Kelautan dan Perikanan Karawang

${ }^{2}$ Fakultas Perikanan Universitas Islam Lamongan

*Email : lilieksoeprijadi@yahoo.com

\begin{abstract}
Abstrak
Sentra perikanan tangkap kota Cirebon, ditunjukkan oleh aktivitas PPN Kejawanan dan tiga TPI lain di sekitarnya. Terdapat 9 Kelompok Usaha Bersama (KUB) yang tumbuh dari aktivitas sub sektor perikanan tangkap kota Cirebon. Penelitian bertujuan menemukan strategi untuk meningkatkan kinerja KUB dalam rangka memberdayakan keluarga nelayan. Metode penelitian deskriptif dengan pendekatan fenomenalogi. Peneliti menggunakan survei terestris untuk melakukan wawancara tertutup dengan responden yang dipilih secara sengaja, mengenai 15 tema yang dianggap merefleksikan aktivitas kebaharian para nelayan. Responden berjumlah 172 orang, memiliki kriteria khusus terutama dari sisi ketokohan, pengalaman, dan keahlian bekerja sebagai nelayan. Hasil penelitian menunjukkan bahwa nelayan kinerja KUB nelayan rendah karena mayoritas terjerat oleh tengkulak. Kinerja KUB hanya dapat ditingkatkan apabila nelayan memiliki komitmen dan konsistensi memberdayakan dirinya; ditandai dengan indikasi berupa meningkatnya kemampuan mengolah dan menghasilkan produk bermutu; serta memiliki dasar pengetahuan yang kuat tentang kebaharian. Bukan sebagaimana saat ini, hal mana nelayan melaut berbekal pengalaman dari hasil meniru pekerjaan yang dilakukan oleh para pendahulu sebelumnya.
\end{abstract}

Kata kunci: KUB, Nelayan, Kinerja, Kota Cirebon

\section{PENDAHULUAN}

Kota Cirebon merupakan salah satu sentra penghasil produk perikanan tangkap yang penting untuk menjamin ketersediaan stok pangan hasil perikanan di provinsi Jawa Barat dan DKI Jakarta. Jenis-jenis ikan yang diperoleh dari hasil produksi perikanan tangkap, dipasarkan dalam bentuk segar maupun olahan; dengan berbagai varian diversifikasi olahan tradisional maupun olahan modern yang digemari masyarakat.

Kelompok Usaha Bersama (KUB) merupakan wadah bagi nelayan yang sangat diharapkan mampu meningkatkan kinerja, tidak hanya di sub sektor perikanan tangkap semata, melainkan mampu mengembangkan diri secara organisasi untuk memiliki berbagai jenis usaha lainnya yang dapat meningkatkan keberdayaan maupun kesejahteraan para nelayan beserta keluarganya. Terdapat 9 KUB nelayan yang para anggotanya melakukan kegiatan operasional penangkapan ikan dengan menggunakan pangkalan perikanan tangkap (fishing base) dari 3 Tempat Pelelangan Ikan dan 1 Pelabuhan Perikanan Nusantara yang ada di kota Cirebon. Masingmasing KUB memiliki armada penangkapan ikan (fishing effort) dilengkapi dengan peralatan penangkapan ikan (fishing gear) yang memadai telah mampu menjangkau seluruh perairan di sekitar Cirebon. Beberapa KUB memiliki beberapa unit perahu dengan kapasitas bobot (Gross Tonage - GT) hingga 5 GT dengan jumlah anak buah kapal sekali melaut 2 - 3 orang; mampu menjangkau daerah penangkapan ikan di laut (fishing ground) yang jauh hingga mendekati perairan sekitar pulau Kalimantan.

Jenis hasil tangkapan beragam. Kegiatan penangkapan ikan yang dilakukan oleh para nelayan anggota KUB hampir berlangsung sepanjang tahun; meskipun pada musim angin dan paceklik ikan; kegiatan penangkapan masih dapat dilakukan di perairan yang tidak jauh dari garis pantai kota Cirebon. 
Permasalahan mendasar yang dihadapi oleh semua KUB di kota Cirebon adalah lemahnya kemampuan untuk mengembangkan organisasi profesi nelayan tersebut menjadi organisasi berorientasi bisnis jangka panjang. Bisnis jangka panjang yang dimaksud adalah bisnis yang berangkat dari pengembangan usaha (diversifikasi) terhadap hasil usaha perikanan tangkap. Hal ini membuat beberapa nelayan justru terjebak kepada tengkulak dan upaya pemasarannya memasuki pasar terbatas (Captive markets). kondisi inilah yang membuat nelayan maupun KUB yang menjadi naungan usaha nya menjadi sulit berkembang. Akibatnya, proses pemberdayaan mandiri nelayan maupun kelompok mengalami kebuntuan, tidak ada inovasi usaha melainkan selalu dihantui oleh jerat urusan pelunasan hutang dan piutang, serta tidak ada kesempatan untuk melakukan usaha alternatif dalam rangka menambah sumber pendapatan bagi keluarga selain dari kegiatan menangkap ikan di laut. Takariani (2015) menegaskan hal tersebut merupakan penyebab maraknya kemiskinan nelayan di Indonesia. Awaka (2011) menyebutkan bahwa ketidak-tauan nelayan terhadap peraturan dan perundangan merupakan salah satu masalah yang juga menjadi penyebab nelayan tidak berani mengembangkan diri dan usahanya. Penelitian bertujuan untuk menyusun strategi meningkatkan kinerja KUB di Kota Cirebon agar memiliki daya saing bisnis dalam jangka panjang.

\section{METODE PENELITIAN}

\section{A. Tempat dan Waktu}

Penelitian dilakukan pada 3 TPI dan 1 PPN berikut 9 KUB nelayan yang ada di kota Cirebon selama tahun 2012 s/d 2018. ketiga TPI tersebut adalah: (1) TPI Kesenden Kelurahan Kesenden Kecamatan Kejaksan; (2) TPI Pesisir Kelurahan Panjunan Kecamatan Lemahwungkuk; (3) TPI
Cangkol Kelurahan Kesepuhan Kecamatan Lemahwungkuk; dan satu PPN yaitu: (4) TPI PPN Kejawanan Kelurahan Pegambiran Kecamatan Lemahwungkuk.

\section{B. Populasi dan Sampel \\ Jumlah populasi nelayan kota Cirebon} seluruhnya diperkirakan mencapai lebih dari 937 orang. Tidak ada angka pasti yang menyebutkan jumlah nelayan secara akurat; karena profesi nelayan bisa beralih ke profesi lain sewaktu-waktu sesuai kebutuhan sosial ekonomi masing-masing. Nelayan adalah orang yang menggantungkan sebagian besar pendapatan keluarga dari kegiatan menangkap ikan di laut dan muara sungai, baik secara mandiri (sendirian) maupun berkelompok sesuai dengan kapasitas perahu dan teknik pemakaian alat tangkap. Tidak seluruh nelayan tergabung sebagai anggota KUB. Sampel penelitian 172 orang terdiri dari seluruh anggota 9 KUB yang berdomisili pada kecamatan Lemahwungkuk dan kecamatan Kajeksan, kota Cirebon.

\section{Metode}

Penelitian bersifat deskriptif dengan pendekatan survei terstruktur dan sistematis. Data bersumber dari informasi langsung para nelayan yang dipilih secara sengaja. Informasi yang diterima di deskripsi dan diberikan bobot untuk menyusun struktur data yang sistematis dan merepresentasikan kondisi empiris pengamatan. Komponen data terdiri dari 9 kata kunci sebagai tema yang disampaikan kepada responden dalam bentuk pertanyaan. Tema pernyataan yang diharapkan antara lain mengenai: (1) Pengalaman sebagai nelayan, (2) Keahlian menangkap ikan, (3) Keterampilan menggunakan peralatan tangkap, (4) Pengetahuan terhadap Fishing Ground, (5) Pengenalan terhadap pergeseran musim ikan, (6) Konsistensi dalam menyiapkan kelengkapan 
penangkapan, (7) Pengetahuan terhadap Fish Handling di laut, (8) Komitmen mempertahankan kesegaran ikan, (9) Penggunaan bahan dan alat pasca tangkap yang benar, (10) Upaya memperoleh harga jual ikan yang tinggi, (11) Pengenalan terhadap usaha alternatif olahan hasil perikanan,

(12) Pemahaman terhadap sanitasi dan higienis,

(13) Komitmen menghasilkan produk bermutu,

(14) Kemampuan diversifikasi produk, dan (15)

Keterlibatan anggota keluarga nelayan.

Pertanyaan ditanyakan secara tertutup dengan pendekatan dialog sederhana pada suasana yang dibuat se-akrab mungkin oleh surveyor. Hal ini bertujuan untuk memperoleh jawaban yang jujur sehingga validitas pernyataan dari jawaban pertanyaan yang diajukan dapat dipertanggungjawabkan secara moril maupun materiil. Pemberian nilai jawaban (skor) menggunakan acuan yang sudah disusun sebelumnya.

Teknik pengolahan data menggunakan matrik shift share sederhana, hal mana nilai selisih ( $\Delta=$ gap skor) digunakan sebagai acuan untuk menemukan akar masalah; dengan analisis akar masalah (cause root analysis) guna menemukan perumusan wujud strategi untuk meningkatkan kinerja KUB nelayan kota Cirebon.

\section{HASIL DAN PEMBAHASAN}

\section{A. Kondisi KUB Nelayan Kota Cirebon}

Nelayan kota Cirebon yang menjadi anggota KUB pada umumnya memiliki tingkat kesejahteraan yang cukup, meskipun pada dasarnya masih sangat terbuka untuk ditingkatkan. Hasil wawancara mendalam secara tertutup menyiratkan bahwa kepercayaan diri serta keterbatasan untuk mengakses sumber permodalan merupakan kendala yang paling banyak dihadapi oleh masing-masing keluarga nelayan.

Usia nelayan mayoritas pada kisaran usia 36 s/d 50 tahun 45,8 \%; berpendidikan tamat SD $51,4 \%$ (suami) dan 62,1\% (istri nelayan); dan $32,4 \%$ anaknya berpendidikan SLTA keatas. Tabel berikut menunjukkan kondisi masing-masing KUB nelayan kota Cirebon yang hanya mengandalkan kinerja pada sub sektor perikanan tangkap; dengan tingkat pendapatan rata-rata yang rendah.

Tabel 1. Kondisi KUB Nelayan Kota Cirebon

\begin{tabular}{|c|c|c|c|c|c|}
\hline Nama & Ketua & $\begin{array}{l}\text { Jumlah } \\
\text { Anggota }\end{array}$ & Aset Usaha & $\begin{array}{l}\text { Total Produksi } \\
\text { (Kg/Tahun) }\end{array}$ & $\begin{array}{c}\text { Pendapatan per } \\
\text { anggota } \\
\text { (Rp/Thn) }\end{array}$ \\
\hline $\begin{array}{l}\text { KUB Sinar Laut, Kel. } \\
\text { Panjunan, Kec. } \\
\text { Lemahwungkuk }\end{array}$ & Taslani & 21 & $\begin{array}{c}\text { Perahu } 0,5 \text { s/d } 1 \\
\text { GT, mesin }<2,5 \\
\text { PK, jaring }\end{array}$ & 10.211 & 13.680 .000 \\
\hline $\begin{array}{l}\text { KUB Sejati, Kel. Panjunan, } \\
\text { Kec. Lemahwungkuk }\end{array}$ & Suhadi & 17 & $\begin{array}{c}\text { Perahu } 3 \text { GT, mesin } \\
\text { disel } 16 \text { - } 24 \mathrm{PK}, \\
\text { jaring rampus }\end{array}$ & 4.775 & 8.150 .136 \\
\hline $\begin{array}{l}\text { KUB Samudra Lestari, Kel. } \\
\text { Kesepuhan, Kec. } \\
\text { Lemahwungkuk }\end{array}$ & Sadikin & 17 & $\begin{array}{l}\text { Perahu } 0,5 \text { s/d } 1 \\
\text { GT, mesin }<2,5 \\
\text { PK, jaring }\end{array}$ & 10.944 & 16.416 .000 \\
\hline $\begin{array}{l}\text { KUB Mitra Jaya, Kel. } \\
\text { Panjunan, Kec. } \\
\text { Lemahwungkuk }\end{array}$ & Sukari & 18 & $\begin{array}{l}\text { Perahu } 0,5 \text { s/d } 1 \\
\text { GT, mesin }<2,5 \\
\text { PK, jaring, sero }\end{array}$ & 16.963 & 25.989 .000 \\
\hline $\begin{array}{l}\text { KUB Kakap Merah, Kel. } \\
\text { Lemahwungkuk, Kec. } \\
\text { Lemahwungkuk }\end{array}$ & Suparman & 19 & $\begin{array}{c}\text { Perahu } 0,5 \text { s/d } 1 \\
\text { GT, mesin }<2,5 \\
\text { PK, jaring, pancing ulur }\end{array}$ & 16.963 & 25.989 .000 \\
\hline $\begin{array}{l}\text { KUB Jenaha, Kel. } \\
\text { Lemahwungkuk, Kec. } \\
\text { Lemahwungkuk }\end{array}$ & Mulyadi & 20 & $\begin{array}{c}\text { Perahu 0,5 s/d } 1 \\
\text { GT, mesin }<2,5 \\
\text { PK, jaring insang, pancing ulur }\end{array}$ & 16.963 & 25.989 .000 \\
\hline $\begin{array}{l}\text { KUB Citra Nelayan, Kel. } \\
\text { Panjunan, Kec. }\end{array}$ & Sura & 18 & $\begin{array}{l}\text { Perahu } 0,5 \text { s/d } 1 \\
\text { GT, mesin }<2,5\end{array}$ & 9.576 & 12.312 .000 \\
\hline
\end{tabular}




\begin{tabular}{|c|c|c|c|c|c|}
\hline Lemahwungkuk & & & PK, jaring insang & & \\
\hline $\begin{array}{l}\text { KUB Muara Laut, Kel. } \\
\text { Kesenden, Kec. Kajeksan }\end{array}$ & Jaeni & 17 & $\begin{array}{c}\text { Perahu 3,5 - 5 GT, } \\
\text { mesin disel } 24 \mathrm{PK}, \\
\text { jaring krakat }\end{array}$ & 87.527 & 68.572 .000 \\
\hline $\begin{array}{l}\text { KUB Bahari Sejahtera, Kel. } \\
\text { Kesenden, Kec. Kejaken }\end{array}$ & Misnem & 18 & $\begin{array}{c}\text { Perahu } 3 \text { GT, mesin } \\
\text { disel } 16 \text { - } 24 \mathrm{PK} \text {, } \\
\text { jaring rampus }\end{array}$ & 9.131 & 61.790 .700 \\
\hline TOTAL & & 165 & & 183.053 & 258.887 .836 \\
\hline
\end{tabular}

Sumber: Supriyadi, L. (2012)

Tidak ditemukan banyak perubahan terhadap data kondisi KUB nelayan kota Cirebon dalam beberapa tahun; kecuali mutasi jumlah anggota akibat alih profesi. Aktivitas sosial dan ekonomi KUB terpaku pada kegiatan rutin seharihari dalam hal menangkap ikan, menjual, dan mengolah sebagian hasil tangkapan ikan secara sederhana (tradisional) pada rumah tangga nelayan; tanpa adanya inovasi dan kreatifitas untuk mengembangan jenis usaha atau menumbuhkan usaha baru yang sebidang dengan kegiatan penangkapan ikan. Pemerintah telah memberikan bantuan alat tangkap baru sesuai dengan kebutuhan nelayan, disertai dengan penjelasan sosialisasi teknik pemakaiannya; akan tetapi sering dijumpai bahwa alat tangkap yang diterima kurang memuaskan para nelayan akibat spesifikasi teknis peralatan yang berbeda dari peralatan sebelumnya; padahal perubahan spesifikasi teknis tersebut merupakan inovasi produsen untuk menciptakan alat tangkap yang lebih baik, lebih ramah lingkungan, dan memperhatikan efektivitas efisiensi kegiatan penangkapan ikan. Hasyim dan Ohoiwutun (2017) juga mengingatkan bahwa penjualan langsung hasil tangkapan ikan kepada tengkulak merupakan indikasi bahwa kesejahteraan nelayan tidak baik karena terus menerus berada di bawah kendali para tengkulak.

\section{B. Kinerja dan Produktivitas}

Mayoritas nelayan kota Cirebon adalah nelayan skala kecil dengan armada perahu < 3 GT dan dijalankan sendiri pada saat melakukan kegiatan penangkapan ikan. Nelayan kecil ini sangat jarang menjual ikan melalui proses pelelangan ikan di PPN Kejawanan; melainkan mendaratkan ikannya di TPI lain untuk disetorkan langsung kepada tengkulak dengan sistem ijon. Besarnya bon uang muka (untuk modal kerja melaut dan memenuhi kebutuhan keluarga) seringkali lebih besar daripada pendapatan hasil melaut. Hal ini menyebabkan nelayan dan keluarganya sangat sulit melepaskan diri dari jerat hutang para tengkulak.

Tengkulak umumnya bertindak sebagai pengijon; bahkan terdapat Pengijon yang bukan tengkulak; hal mana fenomena ini timbul dari akar masalah utang piutang antara nelayan dengan anggota masyarakat yang memiliki modal kuat. Akan tetapi, tengkulak profesional tidak selalu ber konotasi negatif dalam kegiatan bisnis dengan masyarakat. Kegiatan kulak ikan (membeli ikan) adalah kegiatan jual beli biasa yang umumnya dilakukan para pedagang perantara yang telah memiliki saluran menuju ke sentra pemasaran ikan tersendiri yang kuat dan sudah terjalin dengan baik sejak lama; seperti: unit pengolahan, industri makanan, toko, distributor, dan para eksportir.

Pengijon mayoritas adalah warga pendatang dari luar kota Cirebon, memiliki modal untuk dipinjamkan sebagai modal kerja dalam nilai yang besar. Pengijon mengikat nelayan kuat-kuat dengan berbagai cara, untuk memperoleh jaminan keberlanujtan memperoleh ikan hasil tangkapan, atau untuk kepentingan sosial, budaya, politik, agama dan bisnis lainnya. 
Produktivitas sejalan dengan besaran tanggungan nelayan terhadap pengijon, sehingga sulit ditingkatkan. Triyanti dan Firdaus (2016) merekomendasikan agar kehidupan ekonomi nelayan meningkat maka perlu dibantu peningkatan akses masyarakat terhadap kelembagaan ekonomi, mengoptimalkan kelembagaan masyarakat ke dalam setiap program Pemerintah, mengintegrasikan kelembagaan informal dengan kelembagaan formal, serta mengaktifkan koperasi nelayan yang sudah ada ada mendirikan koperasi baru dengan sumber daya manusia pengelola yang profesional. Lebih lanjut Dewi (2016) menegaskan bahwa nelayan perlu didorong untuk lebih bersikap apresiatif terhadap berbagai program agar mampu membangun keterbukaan informasi untuk mengentaskan diri dari kemiskinan. Selain itu Putra (2017) mengingatkan pentingnya peningkatan persentase bagi hasil antara juragan dan anak buah kapal agar pendapatan anak buah kapal lebih baik.

Kinerja bergantung kepada musim dan ketersediaan ikan serta kesesuaian alat tangkap. Guna meningkatkan kinerja yang dapat memperbaiki kesejahteraan nelayan; Juliani (2012) menyarankan adanya pelatihan peningkatan skill nelayan dan penguatan ke akses permodalan.

\section{Strategi Peningkatan Kinerja}

Kinerja nelayan kota Cirebon tergambarkan dalam pernyataan yang disampaikan oleh para nelayan terhadap 15 tema pertanyaan yang ditelusuri; sebagaimana Tabel 2.

Table 2. Hasil Analisis Shift Share

\begin{tabular}{clcc}
\hline Tema & \multicolumn{1}{c}{ Uraian Pernyataan yang Dinilai } & Skor & Gap \\
\hline 1 & Pengalaman sebagai nelayan & 8,29 & 1,52 \\
2 & Keahlian menangkap ikan & 7,65 & 0,87 \\
3 & Keterampilan menggunakan peralatan tangkap & 6,24 & $(-) 0,54$ \\
4 & Pengetahuan terhadap Fishing Ground & 5,76 & $(-) 1,01$ \\
5 & Pengenalan terhadap pergeseran musim ikan & 5,82 & $(-) 0,95$ \\
6 & Konsistensi dalam menyiapkan kelengkapan penangkapan & 6,18 & $(-) 0,60$ \\
7 & Pengetahuan terhadap Fish Handling di laut & 7,71 & 0,93 \\
8 & Komitmen mempertahankan kesegaran ikan & 5,06 & $(-) 1,72$ \\
9 & Penggunaan bahan dan alat pasca tangkap yang benar & 5,41 & $(-) 1,36$ \\
10 & Upaya memperoleh harga jual ikan yang tinggi & 7,41 & 0,64 \\
11 & Pengenalan terhadap usaha alternatif olahan hasil perikanan & 8,35 & 1,58 \\
12 & Pemahaman terhadap sanitasi dan higienis & 6,65 & $(-) 0,13$ \\
13 & Komitmen menghasilkan produk bermutu & 6,06 & $(-) 0,72$ \\
14 & Kemampuan diversifikasi produk & 7,06 & 0,28 \\
15 & Keterlibatan anggota keluarga nelayan & 8,00 & 1,22 \\
\hline
\end{tabular}

Keterangan :

Skor : nilai rata-rata dari jawaban 172 Responden

Gap : selisih skor terhadap nilai rata-rata 15 tema pernyataan yang diperoleh

Berdasarkan Gambar 1 dibawah, tampak bahwa 8 dari 15 tema yang berkaitan dengan kinerja nelayan Kota Cirebon berada pada nilai negatif. Nilai terendah justru adalah pernyataan mengenai komitmen mempertahankan kesegaran ikan (tema 8 gap skor -1,72) dan penggunaan bahan dan alat pasca tangkap yang benar (tema 9 gap skor -1,36). Pengetahuan tentang fishing ground (tema 4 gap skor -1,01) dan pengenalan terhadap pergeseran musim ikan (tema 5 gap skor $0,95)$ juga sangat rendah. Hal ini membuktikan adanya keterkaitan erat dalam efektivitas kinerja nelayan antara tema 8 dengan tema 9 terhadap tema 4 dan tema 5. Rendahnya kinerja nelayan 
yang direfleksikan dalam nilai gap skor terendah tersebut antara lain:

a. Tema 8, menunjukkan bahwa argumen ketergantungan nelayan terhadap tengkulak sangat tinggi. Secara psikologis perasaan bahwa ikan hasil tangkap sudah pasti diambil tengkulak dengan harga yang disepakati dimuka (bahkan sebelum kegiatan penangkapan ikan dilakukan), membuat nelayan enggan memperhatikan kesegaran ikan;

b. Tema 9, memperkuat argumen tema 8 tentang tidak adanya upaya untuk memperoleh tambahan insentif harga dari penjualan ikan hasil tangkapan nya sendiri;

c. Tema 4, membuktikan bahwa pada dasarnya nelayan melaut karena pengalaman (masa kerja yang panjang) dengan tujuan menangkap ikan yang hanya meniru cara kerja nelayan sebelumnya (atau yang pertama kali mengajarkan cara menangkap ikan). Tidak ada pengetahuan yang memadai dari sebagian besar nelayan untuk mengenali fishing ground (tempat berkumpulnya ikan di laut), sehingga efektivitas dan efisiensi kinerja eksplorasi penangkapan ikan menjadi berbiaya tinggi;

d. Tema 5, memperkuat argumen tema 4 bahwa nelayan bekerja di laut tidak memiliki bekal ilmu pengetahuan tentang kebaharian. Pekerjaan yang dikerjakan hanya ikut-ikutan dan meniru nelayan lain, melakukan pengamatan sesuai pendapatnya sendiri tentang bahari dan mengambil kesimpulan sendiri mengenai pergeseran musim ikan, tanpa dilandasi dasar pengetahuan tentang teknologi penangkapan ikan yang memadai (terkini)

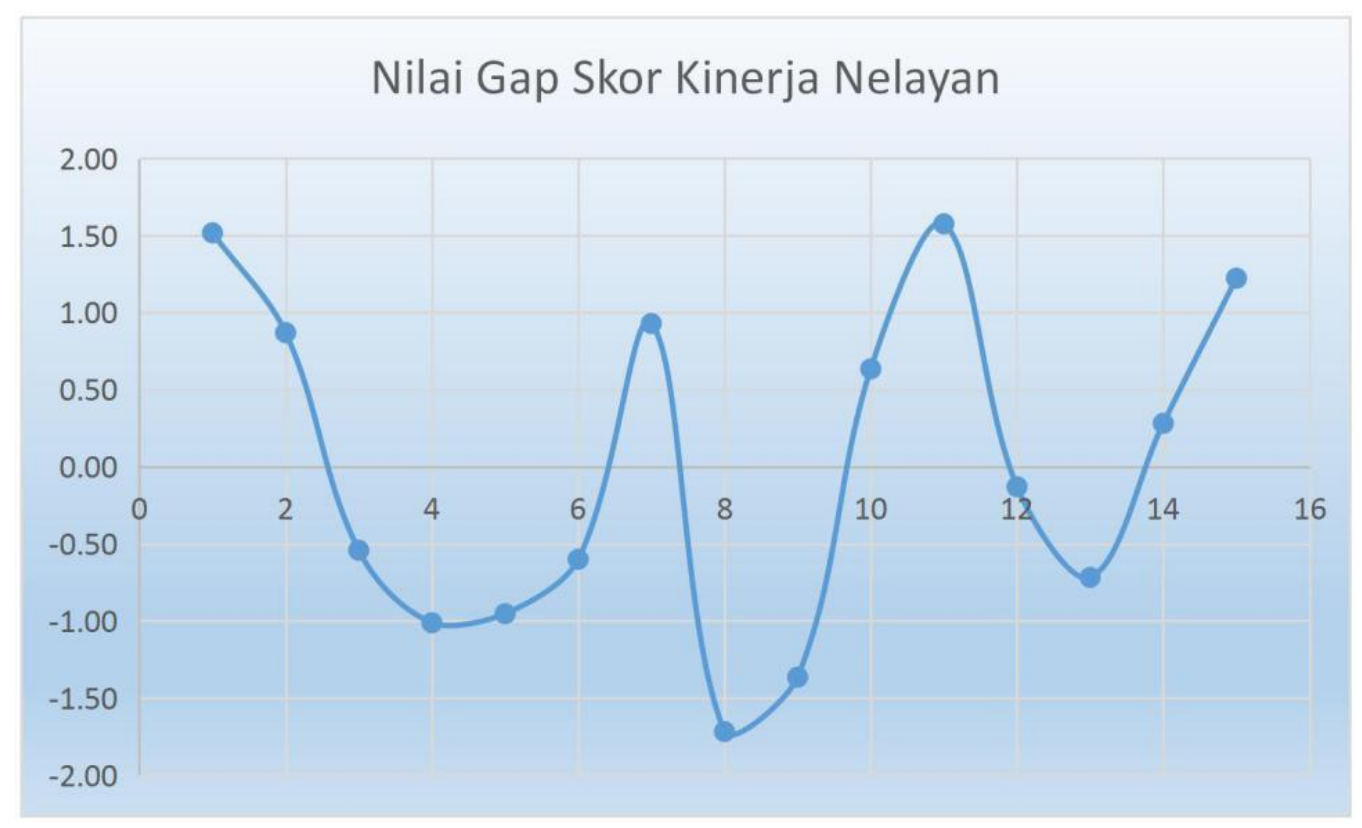

Gambar 1. Diagram Sebaran Nilai Gap Skor Kinerja Nelayan 
Hurnal Grouper, September 2019 Vol 10 (2) : 71-79

ISSN 2086 - 8480

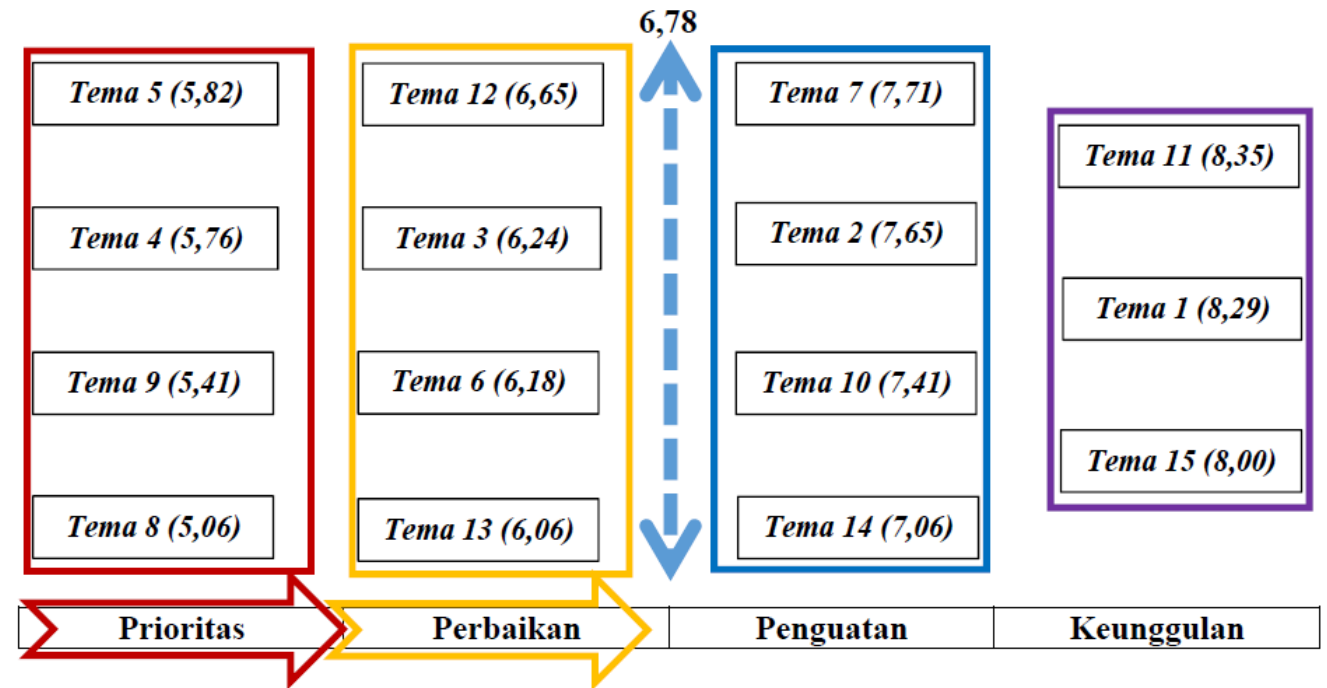

Gambar 2. Diagram Analisis Akar Masalah

Makna keterkaitan antar komponen sebagai dasar untuk merumuskan wujud strategi implementasi. Qodriyatun (2013) dan Istiqomah, dkk. (2018) merekomendasikan peningkatan kinerja untuk pemberdayaan masyarakat pesisir harus dilakukan terintegrasi, artinya: nelayan harus memiliki cukup kemampuan untuk pengolahan ikan hingga pemasarannya. Hal ini sejalan dengan pemikiran Rahim (2018) bahwa memberdayakan masyarakat pesisir terutama para keluarga nelayan harus sekaligus mengajarkan nelayan untuk mampu mengakses pasar dengan teknologi informasi dan memperoleh dukungan permodalan yang tidak bersifat menjerat nelayan ke dalam masalah utang piutang. Rostin (2016) menyatakan bahwa kemampuan nelayan terhadap banyak hal adalah bagian dari modal sosial untuk meningkatkan keberdayaan dan kesejahteraan diri dan keluarganya.

Pengenalan yang luas terhadap dinamika konsumen dan pasar; diharapkan memicu nelayan untuk lepas dari jerat para tengkulak. Melalui aspek pemahaman pasar, nelayan nantinya akan mulai mempertahankan mutu kesegaran ikan dan menggunakan alat bahan pasca tangkap dengan benar untuk mencoba memperoleh tambahan insentif harga jual lebih tinggi. Apabila aspek mutu sudah dipahami, selanjutnya nelayan secara alamiah akan mulai mencoba belajar mengenali laut yang menjadi 'ladang kerjanya' dengan baik dan mendalam. Pengenalan terhadap laut akan disertai dengan upaya memahami fluktuasi pergeseran musim ikan di laut; sehingga perencanaan kerja kebaharian untuk menghasilkan produk hasil tangkap menjadi produk yang diminati konsumen menjadi lebih terencana.

\section{Keberlanjutan}

Keberdayaan dan kesejahteraan nelayan merupakan indikasi yang akan menunjukkan peningkatan kinerja KUB nelayan. Oleh karena itu, para nelayan anggota KUB perlu melakukan upaya mandiri terlebih dahulu untuk memberdayakan dirinya. Hal ini dilandasi oleh pemikiran bahwa: tidak semua anggota nelayan memiliki pemikiran, keinginan, keberanian, kesiapan (mental dan modal), keahlian yang memadai dan kemampuan mengembangkan wira usaha. Tumbuhnya salah satu anggota nelayan menjadi wira usaha baru dapat menjadi stimulasi semangat bagi nelayan lainnya, menyerap tenaga kerja dari anggota keluarga hingga kerabat dan tetangga terdekat, serta membuka jaringan pasar yang sekaligus berimbas terhadap pengetahuan 
khalayak luas tentang kemampuan dan potensi bisnis nelayan kota Cirebon. Hal ini sejalan dengan hasil penelitian Sutrisno (2014) yang menyatakan pentingnya penerapan manajemen sumber daya pesisir secara terpadu untuk meningkatkan kesejahteraan nelayan di kota Cirebon. Tampubolon (2012) menegaskan bahwa pengelolaan sumber daya untuk pemberdayaan masyarakat pesisir harus sejalan dengan peningkatan pengetahuan masyarakat terhadap akses informasi; serta Wantah (2017) mengingatkan bahwa hal tersebut juga harus didukung oleh aspek pengetahuan dan tingkat pendidikan yang baik.

\section{KESIMPULAN DAN SARAN}

\section{A. Kesimpulan}

Strategi untuk meningkatkan kinerja kelompok usaha bersama nelayan di kota Cirebon; harus dilakukan bertahap dimulai dari 4 prioritas masalah yang harus ditangani yaitu: a) Komitmen mempertahankan kesegaran ikan, b) Penggunaan bahan dan alat pasca tangkap yang benar, c) Pengetahuan terhadap fishing ground, dan d) Pengenalan terhadap pergeseran musim ikan. Terdapat 4 tahapan strategi terhadap 15 tema untuk pemecahan masalah peningkatan kinerja KUB yaitu: a) skala prioritas, b) tindakan perbaikan, c) upaya penguatan, dan d) komitmen mempertahankan keunggulan yang sudah ada.

\section{B. Saran}

Perlunya memberikan pendampingan kepada masing-masing KUB nelayan kota Cirebon secara intensif agar anggota nelayan pada masing-masing kelompok memahami langkah strategi melepaskan diri dari jerat bisnis tengkulak yang membeli ikan secara ijon. Praktik seperti ini harus diketahui, dimengerti, dan dipahami bahwa selama ini telah membelenggu para nelayan secara ekonomi; sehingga nelayan tidak mempunyai gairah untuk mengembangkan diri yang pada akhirnya dapat meningkatkan kinerja KUB nya.

Dibutuhkan kebersamaan yang mana peran untuk menyatukan persepsi dan pandangan hidup nelayan untuk berkembang dapat dimainkan bersama antara Pemerintah, Akademisi, dan dengan melibatkan pengaruh serta peran aktif para Tokoh Agama setempat.

\section{DAFTAR PUSTAKA}

Awaka, M.Q. 2011. Pemberdayaan Masyarakat Pesisir (Nelayan Tradisional) Melalui Efektivitas Perundangan dan Peraturan Yang Berlaku Dalam Upaya Menanggulangi Kemiskinan di Kabupaten Bengkayang Kalimantan Barat. Jurnal Fakultas Hukum Universitas Tanjung Pura, Pontianak.

Dewi, A.A.I.A.A. 2016. Model Pengelolaan Wilayah Pesisir Berbasis Masyarakat: Community Based Development. De Jure. Jurnal Penelitian Hukum. ISSN 1410-5632 Vol. 18 No. 2, Juni 2018.

Hasyim, C.L., dan Ohoiwutun, E.C. 2017. Peran Komunikasi Dalam Pemberdayaan Nelayan Tradisional Pada Masyarakat Pesisir di Kabupaten Maluku Tenggara. Jurnal Penelitian Komunikasi dan Pembangunan Vol. 18 No. 1 Juni 2017.

Istiqomah, T., Pudjihardjo, M., Sumarno, Yanuwiadi, B. 2018. Analisis Potensi Keberlanjutan Multi Usaha Sub Sektor Perikanan di Kabupaten Sidoarjo. Jurnal Keberlanjutan Kelautan dan Perikanan Vol. 1 No. 4.

Juliani. 2012. Trend Tingkat Kesejahteraan Nelayan di Wilayah Pesisir Kabupaten Kutai Kartanegara. Jurnal Marine Fisheries Vol 3 No. 2.

Putra, T.R. 2017. Analisis Upah Sistem Bagi Hasil Anak Buah Kapal Pada Perahu Penangkap Ikan di Kabupaten Lamongan (Studi Kasus Perahu Ijon-Ijon Payangan Pada Masyarakat Nelayan di Kelurahan Brondong dan Kelurahan Blimbing). Media Trend. Berkala Kajian Ekonomi dan Studi Pembangunan Vol. 12 No. 2. 
Qodriyatun, S.N. 2013. Peningkatan Kesejahteraan Masyarakat Pesisir di Kota Batam Melalui Pemberdayaan Masyarakat. Jurnal Apresiasi Vol. 4 No. 2, Desember 2013.

Rahim, A. 2018. The Empowerment Strategy of The Traditional Fisherman's Wives in The Coastal Area of Barru Regencey, South Sulawesi. Journal of Socioeconomics and Development Vol. 1 No. 12018.

Rostin. 2016. The Effect of Economic Empowerment of the Coastal Communities and Social Capital on Coastal Community Welfare. The International Journal of Engineering And Sciences (IJES) Vol. 5 Issue 2.

Supriyadi, L. 2012. Model Kelompok Usaha Bersama (KUB) Based Knowledge Sebagai Strategi Pemberdayaan Masyarakat Nelayan (Studi Kasus Diversifikasi Usaha di Wilayah Padat Tangkap di Kota Cirebon). Publikasi Ilmiah Disertasi. Fakultas Perikanan dan Ilmu Kelautan Universitas Brawijaya Malang.

Sutrisno, E. 2014. Implementasi Pengelolaan Sumber Daya Pesisir Berbasis Pengelolaan Wilayah Pesisir Secara Terpadu Untuk Kesejahteraan Nelayan (Studi di Perdesaan Nelayan Cangkol
Kelurahan Lemahwungkuk Kecamatan Lemahwungkuk Kota Cirebon). Lembaga Penelitian Universitas Swadaya Gunung Jati Cirebon. Jurnal Dinamika Hukum Vol. 14 No. 12014.

Takariani, C.S.D. 2015. Opini Nelayan Tentang Akses Informasi Publik. Jurnal Penelitian dan Komunikasi Vol. 18 No. 2 Desember 2015.

Tampubolon, D. 2012. Strategi Pemberdayaan Masyarakat Pesisir di Kabupaten Kepulauan Meranti. Lembaga Penelitian Universitas Riau. Jurnal Sorot Vol. 8 No. 2.

Triyanti, R. dan Firdaus, M. 2016. Tingkat Kesejahteraan Nelayan Skala Kecil Dengan Pendekatan Penghidupan Berkelanjutan di Kabupaten Indramayu. Jurnal Sosial Ekonomi Kelautan Perikanan Vol. 11 No. 12016.

Wantah, E. 2017. Pemberdayaan Nelayan Berbasis Pendidikan Ekonomi dan Potensi Pesisir di Kabupaten Minahasa Utara. Jurnal Teori dan Praktis Pembelajaran IPS. Fakultas Ilmu Sosial Universitas Negeri Malang. 